\title{
PRINCIPAL EARTHQUAKES IN NEW ZEALAND IN 1995
}

\author{
T. H. Webb'
}

We have again had a busy year for earthquakes in 1995 , continuing the pattern of increased activity since 1990 . The February 6 Waitangi Day earthquake, of magnitude 6.8, was felt from Auckland to Christchurch and also in the Chatham Islands. This earthquake was located $85 \mathrm{~km}$ offshore from East Cape, so damage was relatively minor for an event of this size. The mainshock was followed by many aftershocks, the largest of which occurred four days later and had a magnitude of 6.2 - a fairly large earthquake in its own right. Institute staff are still working on locating the aftershocks, with some 2000 located within the first week. Fairly large earthquakes that occurred in Fiordland in 1993 and near Arthurs Pass in 1994 were also located in remote ares, so we have been fortunate that none of these were located near a major population centre.

An earthquake that occurred during National Radio's Morning Report programme on March 23 was widely felt throughout the country. It was located at the northern end of the Marlborough Sounds at a depth of $76 \mathrm{~km}$, and was of magnitude 5.9 . It is unusual for an event of this size to be felt from Auckland to Dunedin, but part of the felt extent can be attributed to the fact that Morning Report listeners were alerted to the shaking. It also gave people the rare opportunity to experience the propagation time of seismic waves in that the earthquake was felt in Dunedin and Auckland about two minutes after it was felt in Wellington. Damage was only minor with goods knocked off shelves in some Nelson shops.

For the second year in succession Arthurs Pass has had more than its fair share of earthquakes. On May 29 a magnitude 5.5 earthquake rocked the township. This event was located near the aftershock zone of the 1994 June magnitude 6.7 earthquake, and triggered a landslide that closed the Otira Gorge road. This was followed on November 24 by a magnitude 5.9 event, this time located some $20 \mathrm{~km}$ further to the east, just north of Cass. It caused some ground damage in the remote Poulter River area. It is possible that the Cass earthquake was triggered by stress changes associated with the 1994 event and this is being investigated. This possibility has important ramifications for short-term seismic hazard estimation and may also contribute important new information on how faults weaken when loaded.
Three other large earthquakes occurred during the year. On June 4 a deep magnitude 6.9 earthquake occurred $450 \mathrm{~km}$ to the north of New Zealand. This was felt in Hawkes Bay and Wellington. A shallow magnitude 7.1 earthquake occurred near Raoul Island on July 4. This caused strong shaking at Raoul, but was not reported as felt in New Zealand. Finally, a deep magnitude 6.4 earthquake, located $20 \mathrm{~km}$ south of Hawera, occurred on September 20 and was felt from Wanganui to Dunedin

The eruption of Mt Ruapehu in September created nationwide interest. Three types of seismic activity typically accompany volcanic eruptions. These are volcanic tremor, caused by resonance in the volcano's plumbing system, low frequency earthquakes, often associated with actual eruptions, and "normal" earthquakes associated with movement of magma at depth. In the case of this eruption, both tremor and low frequency earthquakes were common, but few "normal" earthquakes occurred, consistent with little movement of magma and a relatively small eruption. However, coincidental with the eruption were four small felt earthquakes within four days, located from Wanganui to South Westland. Their distance from Mit Ruapehu rules out any direct relationship to the eruption. A more likely candidate for related activity is a swarm of earthquakes that occurred near National Park in January and March/April, of which six were felt in Ohakune. The link between this swarm and the subsequent eruption is currently being investigated.

The Institute of Geological and Nuclear Sciences operates a seismograph at Rarotonga which clearly records French nuclear tests detonated at Mururoa. Between September and December five tests, ranging in yield from 8 to 100 kilotons, were detected. While a link between nuclear tests and earthquakes is often suggested, there is in fact no relationship. Large earthquakes around the rim of the Pacific Ocean are frequent. Furthermore, it is earthquakes, rather than explosions, that are likely to trigger other earthquakes. Such triggering has only been observed within a few hundred kilometers of very large earthquakes, which have a triggering effect many times greater than the largest nuclear tests. 